\title{
Primary Cilia on Horizontal Basal Cells Regulate Regeneration of the Olfactory Epithelium
}

\author{
Ariell M. Joiner, ${ }^{1 \star}$ Warren W. Green, ${ }^{2 \star}$ (Jeremy C. McIntyre, ${ }^{2}$ (B) Benjamin L. Allen, ${ }^{3}$ James E. Schwob, ${ }^{4}$ \\ and Jeffrey R. Martens $s^{1,2}$ \\ ${ }^{1}$ Department of Pharmacology, University of Michigan Medical School, Ann Arbor, Michigan 48109-5632, ${ }^{2}$ Department of Pharmacology \& Therapeutics, \\ University of Florida, College of Medicine, Gainesville, Florida 32610-0267, 3. Department of Cell and Developmental Biology, University of Michigan Medical \\ School, Ann Arbor, Michigan 48109-2200, and ${ }^{4}$ Department of Developmental, Molecular, and Chemical Biology, Tufts University School of Medicine, \\ Boston, Massachusetts 02111
}

The olfactory epithelium $(\mathrm{OE})$ is one of the few tissues to undergo constitutive neurogenesis throughout the mammalian lifespan. It is composed of multiple cell types including olfactory sensory neurons (OSNs) that are readily replaced by two populations of basal stem cells, frequently dividing globose basal cells and quiescent horizontal basal cells (HBCs). However, the precise mechanisms by which these cells mediate $\mathrm{OE}$ regeneration are unclear. Here, we show for the first time that the HBC subpopulation of basal stem cells uniquely possesses primary cilia that are aligned in an apical orientation in direct apposition to sustentacular cell end feet. The positioning of these cilia suggests that they function in the detection of growth signals and/or differentiation cues. To test this idea, we generated an inducible, cell type-specific Ift 88 knock-out mouse line (K5rtTA;tetOCre;Ift $\left.88^{\text {flffl }}\right)$ to disrupt cilia formation and maintenance specifically in HBCs. Surprisingly, the loss of HBC cilia did not affect the maintenance of the adult OE but dramatically impaired the regeneration of OSNs following lesion. Furthermore, the loss of cilia during development resulted in a region-specific decrease in neurogenesis, implicating $\mathrm{HBC}$ in the establishment of the OE. Together, these results suggest a novel role for primary cilia in $\mathrm{HBC}$ activation, proliferation, and differentiation.

Key words: cilia; neurogenesis; olfaction; olfactory sensory neuron; stem cells

Significance Statement

We show for the first time the presence of primary cilia on a quiescent population of basal stem cells, the horizontal basal cells (HBCs), in the olfactory epithelium (OE). Importantly, our data demonstrate that cilia on HBCs are necessary for regeneration of the $\mathrm{OE}$ following injury. Moreover, the disruption of $\mathrm{HBC}$ cilia alters neurogenesis during the development of the $\mathrm{OE}$, providing evidence that HBCs participate in the establishment of this tissue. These data suggest that the mechanisms of penetrance for ciliopathies in the $\mathrm{OE}$ extend beyond that of defects in olfactory sensory neurons and may include alterations in $\mathrm{OE}$ maintenance and regeneration.

\section{Introduction}

Neurogenesis occurs from the self-renewal and differentiation of neural stem cells (NSCs; Gage, 2000). While prevalent during development, NSCs are also found in the adult nervous

Received May 1, 2015; revised Sept. 1, 2015; accepted Sept. 3, 2015.

Author contributions: A.M.J., J.C.M., and J.R.M. designed research; A.M.J., W.W.G., and J.C.M. performed research; A.M.J., W.W.G., J.C.M., and J.R.M. analyzed data; A.M.J., W.W.G., J.C.M., B.L.A., J.E.S., and J.R.M. wrote the paper.

This work was funded by National Institutes of Health Grants R01-DC-009606 (to J.R.M.); T32-DC-00011 and F31-DC-013496 (to A.M.J.); and K99-DC-013555 (to J.C.M.). B.L.A. and J.R.M. were supported by a Research Team Grant from the University of Michigan (enter for Organogenesis. A.M.J. was also supported by the Rackham Merit Fellowship from the Rackham Graduate School, University of Michigan. We thank Drs. Andrzej Dlugosz, Bradley Yoder, and David Clapham for their mouse lines. We also thank Corey Williams for the contribution of graphic art.

*A.M.J. and W.W.G. are co-first authors.

The authors declare no competing financial interests. system, in the olfactory epithelium (OE), subventricular zone (SVZ) of the lateral ventricle, and the subgranular zone of the hippocampus (Gage, 2000; Alvarez-Buylla and GarciaVerdugo, 2002; Lie et al., 2004). Factors and mechanisms that regulate cell proliferation, migration, differentiation, and survival during development can be active in the adult nervous system, allowing for tissue repair and neuroplasticity (for review, see Lie et al., 2004). Unlike most sensory systems, the OE is able to reconstitute both neuronal and non-neuronal pop-

Correspondence should be addressed to Jeffrey R. Martens, Department of Pharmacology \& Therapeutics, University of Florida, College of Medicine, 1200 Newell Drive, ARB R5-234A, Gainesville, FL 32610-0267. E-mail: martensj@ufl.edu.

DOI:10.1523/JNEUROSCI.1708-15.2015

Copyright $\odot 2015$ the authors $\quad 0270-6474 / 15 / 3513761-12 \$ 15.00 / 0$ 
ulations following injury and neuronal death via the action of resident populations of olfactory stem cells (Graziadei and Graziadei, 1979; Calof and Chikaraishi, 1989; Edge and Chen, 2008). Olfactory sensory neurons (OSNs) are unique in that they directly contact both the external environment and the brain. While this direct contact allows OSNs to detect odors, it also exposes the OE to insults from toxins, bacteria, and viruses leading to cell death. Therefore, the capacity for neurogenesis and the replacement of OSNs is critical for maintaining this important sensory system.

The OE is composed of OSNs, supporting sustentacular (SUS) cells, Bowman's gland duct cells, and two groups of basally located stems cells, globose basal cells (GBCs) and horizontal basal cells (HBCs). GBCs and HBCs are considered to be progenitor or stem cells of the $\mathrm{OE}$, and are capable of promoting regeneration and neurogenesis both for tissue homeostasis and in response to injury (Barber, 1982; Costanzo, 1991; Leung et al., 2007). GBCs are a heterogeneous population of actively cycling cells that are composed of immediate neuronal progenitors and transit-amplifying precursors committed to producing neurons as well as multipotent precursors that can produce non-neuronal cells (Jang et al., 2014). HBCs are a homogeneous population of multipotent, quiescent cells (Holbrook et al., 1995; Carter et al., 2004; Iwai et al., 2008). Following the selective death of olfactory neurons, as occurs in response to olfactory bulbectomy, primarily GBCs replace OSNs through differentiation, while HBCs remain quiescent (Caggiano et al., 1994; Huard et al., 1998; Leung et al., 2007). In lesion models, such as exposure to methyl bromide or ablation with methimazole (MMI), in which SUS cells and GBCs are affected, HBCs have been shown to contribute to the regeneration of the OE (Leung et al., 2007; Iwai et al., 2008). While the cell types involved are known, the precise mechanisms controlling regeneration and homeostasis are unclear. Importantly, the molecular regulation of olfactory basal stem cells, including their activation and proliferation in response to injury and cell fate determination during differentiation, remains largely unknown.

Primary cilia have important roles in cell proliferation, differentiation, and regulation of the cell cycle (for review, see Irigoín and Badano, 2011). There is growing evidence that primary cilia regulate neurogenesis and/or proper differentiation of adult stem cells into amplifying progenitor cells or glial cells in the SVZ and hippocampus (Amador-Arjona et al., 2011; Kumamoto et al., 2012; Tong et al., 2014). Consequently, when cilia are disrupted in these systems, cilia-mediated signaling pathways, such as sonic hedgehog, and cilia-modulated signaling pathways, such as Wnt, are also disrupted (Kumamoto et al., 2012; Tong et al., 2014). These findings demonstrate the important role that cilia play in the signaling pathways that are essential for proper cell differentiation during development and adult homeostasis.

Here, we show that HBCs possess primary cilia, suggesting a potential mechanism for the molecular regulation of olfactory basal stem cells in the OE. In mice in which HBCs lacked cilia, the OE showed limited regeneration following the lesion, with a significant reduction of mature OSNs. Additionally, when HBC cilia were removed early in development, specific regions of the $\mathrm{OE}$ were found to have a significant reduction in OSNs. These data identify $\mathrm{HBC}$ cilia as a previously unrecognized signaling structure in the $\mathrm{OE}$, provide mechanistic insight into the regulation of HBCs during olfactory regeneration, and indicate a potential role for HBCs in OE development.

\section{Materials and Methods}

Mouse strains and genotyping. All mice were maintained on a mixed genetic background. Transgenic Arl13b-EGFP tg mice were provided by David Clapham (Harvard University, Cambridge, MA). EGFP-CETN2 mice were obtained from The Jackson Laboratory (stock \#008234; Higginbotham et al., 2004). Conditional deletion of Ift88 from olfactory horizontal basal cells was achieved by the use of a doxycycline (dox)inducible Cre recombinase (Cre) mouse model. This model used mice carrying the following three alleles: (1) a Keratin5 (K5) promoter driving expression of the reverse tetracycline transactivator ( $r t T A$; K5rtTA; Diamond et al., 2000); (2) a tetracycline operator (TetO) to permit expression of Cre (TetOCre; Mucenski et al., 2003); and (3) a floxed Ift8 ff// to ablate cilia (the $\Delta$ allele has exons 4-6 deleted from Ift88; Haycraft et al., 2007). K5rtTA and TetOCre mice provided by Andrzej Dlugosz (University of Michigan, Ann Arbor, MI). Ift $88^{f l / \Delta}$ mice were provided by Bradley Yoder (University of Alabama at Birmingham, Birmingham, AL). Removal of Arl13b from olfactory horizontal basal cells was achieved using a similar strategy with a floxed Arl13b (exon 2; Su et al., 2012) mouse provided by Tamara Caspary (Emory University, Atlanta, GA). All mice of either sex were housed and maintained according to the University of Michigan and University of Florida institutional guidelines. All protocols for mouse experimentation were approved by the University of Michigan and the University of Florida Committees on the Use and Care of Animals. Genotyping was performed using primers and PCR parameters from previously published studies, which are referenced above.

Doxycycline transgene induction and olfactory epithelium lesion. Mice were fed doxycycline chow ( $200 \mathrm{mg} / \mathrm{kg}$ doxycycline, Bio-Serv) and water (200 $\mu \mathrm{g} / \mathrm{ml}$ doxycycline, $5 \%$ sucrose, Thermo Fisher) starting at either embryonic day 16 (E16) or postnatal day 28 (P28) and remained on a doxycycline-containing diet until they were killed. Based on an approximate daily food intake of $4 \mathrm{~g} /$ mouse and water intake of $6 \mathrm{ml} / \mathrm{mouse}$ (Bachmanov et al., 2002), mice consumed $\sim 2 \mathrm{mg}$ of doxycycline/d (0.8 mg in chow and $1.2 \mathrm{mg}$ in water). P28 doxycycline-treated $\mathrm{K} 5 \mathrm{rtTA}$; TetOcre; Ift $88^{f l / f l}$ mice or K5rtTA;TetOcre;Arl13b ${ }^{f l / f l}$ mice and respective control littermates received an intraperitoneal injection of methimazole (2-mercapto-1-methylimidazole, $75 \mathrm{mg} / \mathrm{kg}$ in sterilized $1 \times$ PBS; SigmaAldrich) 4 weeks after the start of the doxycycline-containing diet. These mice were maintained on a doxycycline-containing diet until they were killed 8 weeks after methimazole treatment.

Tissue collection and preparation. Mice were anesthetized with $30 \%$ Fluriso (isoflurane, VetOne), transcardially perfused with $4 \%$ paraformaldehyde (PFA), and decapitated, and their heads were fixed in $4 \%$ PFA for $12-16 \mathrm{~h}$ at $4^{\circ} \mathrm{C}$. Tissue was then decalcified in $0.5 \mathrm{M}$ EDTA (Thermo Fisher $) / 1 \times$ PBS overnight at $4^{\circ} \mathrm{C}$; cryoprotected in $10 \%(1 \mathrm{~h}), 20 \%(1 \mathrm{~h})$, and $30 \%$ sucrose $/ 1 \times$ PBS overnight at $4^{\circ} \mathrm{C}$; and frozen in OCT compound (Tissue Tek). Sections of the olfactory epithelium and olfactory bulb (OB) that were 10-12 $\mu \mathrm{m}$ in size were collected on a Leica CM1860 cryostat.

Immunohistochemistry. For all immunofluorescence, antigen retrieval was used. For antigen retrieval, tissue sections were rinsed in $1 \times$ PBS to remove OCT then incubated in citrate buffer, $\mathrm{pH} 6.0$, for $30 \mathrm{~min}$ at $90^{\circ} \mathrm{C}$, cooled for $20 \mathrm{~min}$ at room temperature, then washed with distilled water for $5 \mathrm{~min}$. Sections were blocked with $2 \%$ donkey or goat serum and $1 \%$ BSA in $1 \times$ PBS, and were incubated overnight in primary antibody. Antibodies were used at the following dilutions: mIgG2a anti-p63 (1:200; BioCare Medical); mIgG2a anti-ARL13B (1:500; Neuromab); rabbit anti-ARL13B (1:500; Proteintech); mIgG1 anti- $\gamma$-tubulin (1:500; Sigma-Aldrich); rabbit anti-K5 (1:2500; Covance); chicken anti-green fluorescent protein (GFP; 1:500; Abcam); rabbit anti-K18 (1:500; Abcam); mIgG1 anti-MASH1 (1:100; BD PharMingen); mIgG2b anti-SEC8 (1:500; BD Transduction Laboratory); rabbit anti-lysine-specific demethylase 1 (LSD1; 1:500; Abcam); goat antiolfactory marker protein (OMP; 1:1000; Wako Chemicals); mouse anti-Cre (1:500; Millipore); mouse anti- $\alpha$ acetylated tubulin (1:1000; Sigma); rabbit anti-AC3 (1:2000; EnCor Biotechnology); and rabbit anti-tyrosine hydroxylase (TH; 1:500; Millipore). Sections were washed in $1 \times$ PBS three times for 5 min each at room temperature and then incubated with Alexa Fluorconjugated secondary antibodies $(1: 1000)$ for $1 \mathrm{~h}$ at room temperature. Tissue sections were then incubated with DAPI ( $5 \mathrm{mg} / \mathrm{ml}$; Invitrogen) for $5 \mathrm{~min}$, 

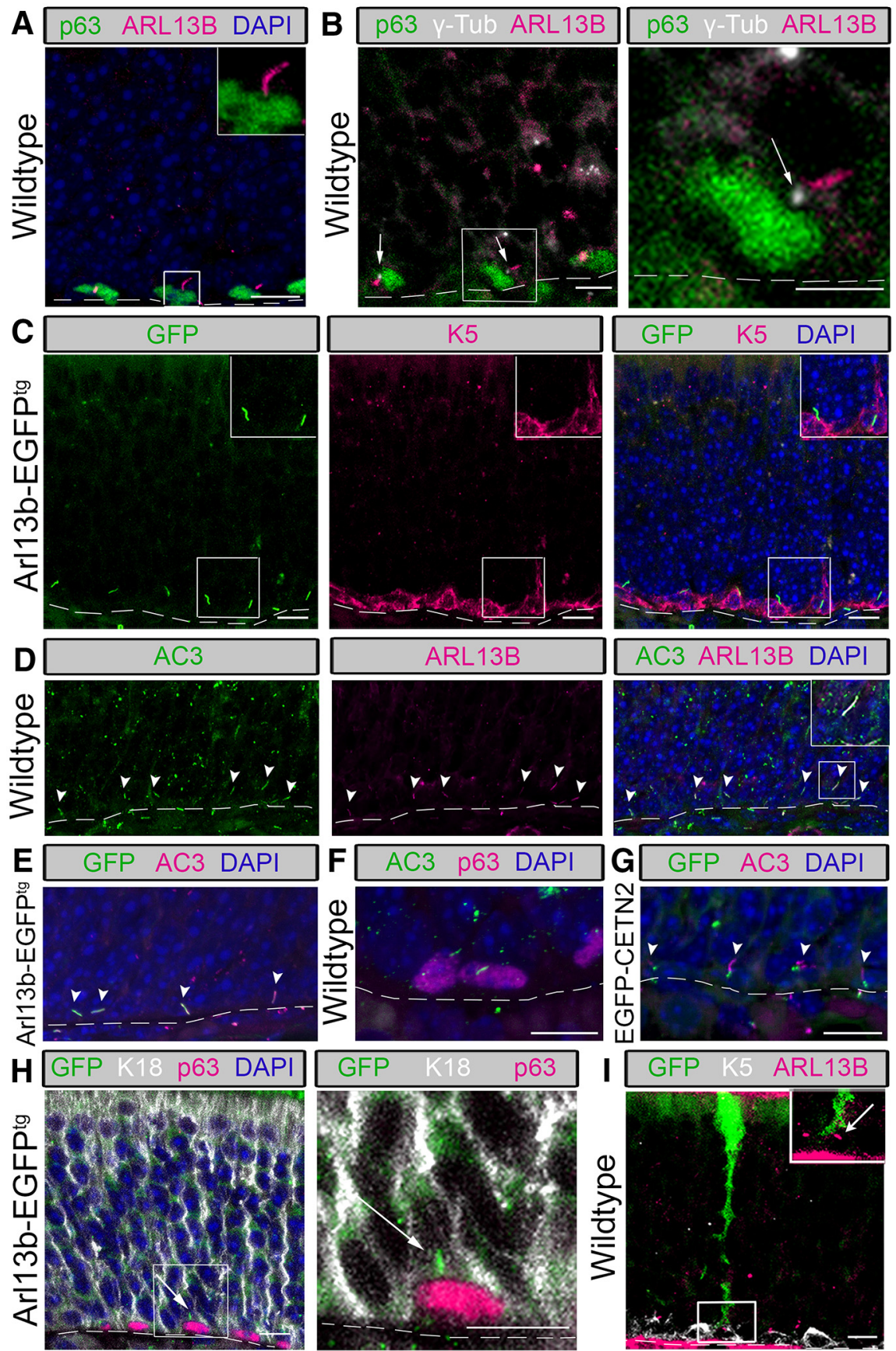

Figure 1. $H B C$ s possess primary cilia. Immunofluorescence staining was performed on tissue from the olfactory epithelium of 3 to 6-week-old wild-type, Arl13b-EGFPtg , and EGFP-CETN2 mice. A, p63-labeled HBCs possess ARL13B-labeled cilia (inset, magnified image). Scale bars, $10 \mu \mathrm{m}$. $\boldsymbol{B}$, Cilia extend from $\gamma$-tubulin-labeled basal bodies (arrows). Low-magnification view (left) and high-magnification view (right) of ciliated HBC. Scale bars, $5 \mu \mathrm{m}$. C, In Arl13b-EGFPtg mice, K5-labeled HBCs possess GFP ${ }^{+}$cilia (inset, magnified image). Scale bars, $10 \mu \mathrm{m}$. D, HBC cilia labeled with canonical cilia markers AC3 and ARL13B (arrowheads). $\boldsymbol{E}$, In Arl13b-EGFPtg mice, AC3 labels GFP ${ }^{+}$cilia (arrowheads). $\boldsymbol{F}$, p63-labled HBCs possess AC3-labeled cilia. $\boldsymbol{G}$, In EGFP-CETN2 mice, GFP-expressing basal bodies possess AC3 ${ }^{+}$cilia (arrowheads). $\boldsymbol{H}$, In Arl13b-EGFPtg mice, GFP ${ }^{+}$cilia (arrows) project from p63labeled HBCs into the interstitial space between HBCs and K18-labeled SUS cell end feet (inset, magnified image). Scale bars, $5 \mu \mathrm{m}$. I, In wild-type mice intranasally infected with adenovirus containing GFP, K5-labeled HBCs possess ARL13B-labeled cilia (see arrow) that project into the interstitial space between an $\mathrm{HBC}_{\text {and GFP }}{ }^{+}$end foot of a SUS cell (see inset for higher magnified image). Scale bar, $10 \mu \mathrm{m} . N=10$ total mice for all immunostaining. Dashed lines, Basement membrane.

washed two times with $1 \times$ PBS, and then sealed with coverslips mounted with ProLong Gold (Invitrogen).

For the detection of Cre, tissue sections were rinsed in $1 \times$ PBS to remove OCT, puddled with citrate buffer, and steamed for $10 \mathrm{~min}$ in a glass jar in a hot water bath. Sections were blocked with $2 \%$ donkey or goat serum/5\% dry non-fat milk/4\% BSA/1\% TTX100 in $1 \times$ PBS and incubated overnight in primary antibody. For detection of GFP, tissue sections were rinsed in $1 \times$ PBS to remove OCT, puddled with citrate buffer, and steamed for 10 min in a glass jar in a hot water bath. Sections were blocked with $2 \%$ donkey or goat serum/ $0.3 \%$ TTX100 in $1 \times$ PBS and incubated overnight in primary antibody. For triple staining with MASH1, SEC8, and LSD1 or OMP and ATub, mouse antibodies or OMP were incubated together overnight, and LSD1 or ATub, respectively, were incubated for $1 \mathrm{~h}$ the following day.

Image processing and quantification. Images were captured using a Nikon A1R confocal microscope. ImageJ software was used to measure the length of the $\mathrm{OE}$ (in micrometers) in each image, to count specific cell types with the cell-counter plugin and to measure the $\mathrm{TH}$ intensity. To quantify cell types, 10-15 images were taken from the dorsal-medial, dorsal-lateral, ventralmedial, and ventral-lateral regions, across three to four sections of the OE. Cell counts were averaged and converted to the number of cells per millimeter of OE. Quantification was performed for $N=3-6$ mice in all control, iHBC-IFT88, and iHBC-ARL13B groups, unless otherwise stated. Reported $N$ values represent the number of mice examined. Measurements of $\mathrm{TH}$ intensity were quantified for all glomeruli in each of three to four sections of the $\mathrm{OB}$ in four iHBCIFT8 8 and four control mice using Image software. A blind experimental paradigm was used to eliminate bias during image processing and quantification.

Statistics. Statistical significance was determined using an unpaired $t$ test with GraphPad Prism software. Data are presented as the mean \pm SEM with two-tailed $p$ values $<0.05$ considered to be significant.

\section{Results}

Olfactory stem cells possess primary cilia

ARL13B is a small Ras GTPase that regulates ciliogenesis and cilia function (Cantagrel et al., 2008; Higginbotham et al., 2013; Kasahara et al., 2014; Bangs et al., 2015). While immunostaining the OE of wild-type mice for endogenous ARL13B, we made a fortuitous discovery of what appeared to be cilia projecting from cells located just above the lamina propria (Fig. 1). To determine whether these primary cilia were on a specific olfactory cell type, we immunolabeled the OE for the basal body marker $\gamma$-tubulin, and the nuclear marker p63, which labels HBCs (Packard et al., 2011). The staining revealed $\mathrm{ARL}_{13 \mathrm{~B}}{ }^{+}$cilia projecting from basal bodies located within HBCs (Fig. $1 A, B$ ). To confirm the presence of cilia using a transgenic marker, we analyzed the OE of mice expressing an ARL13B-GFP fusion protein (Arl13b-EGFP ${ }^{t g}$; Delling et al., 2013) labeled with a second HBC marker, K5 (Holbrook et al., 1995). Similar to the endogenous staining, 
A

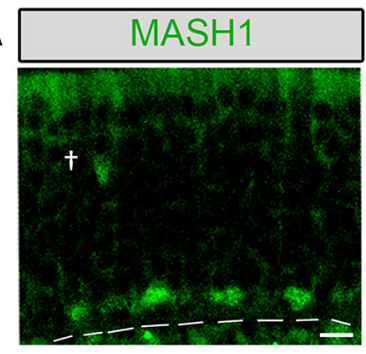

B

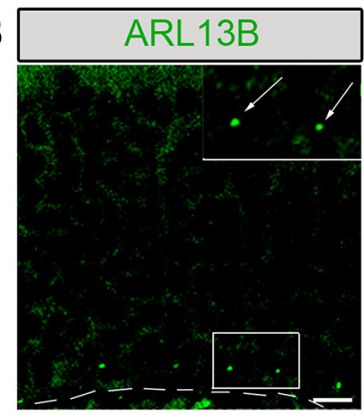

C

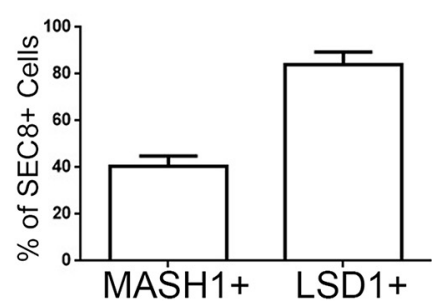

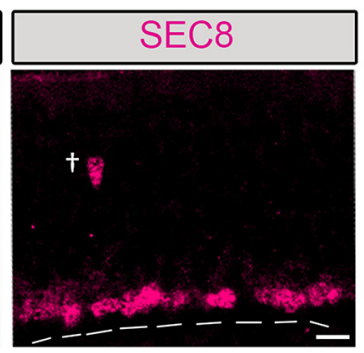
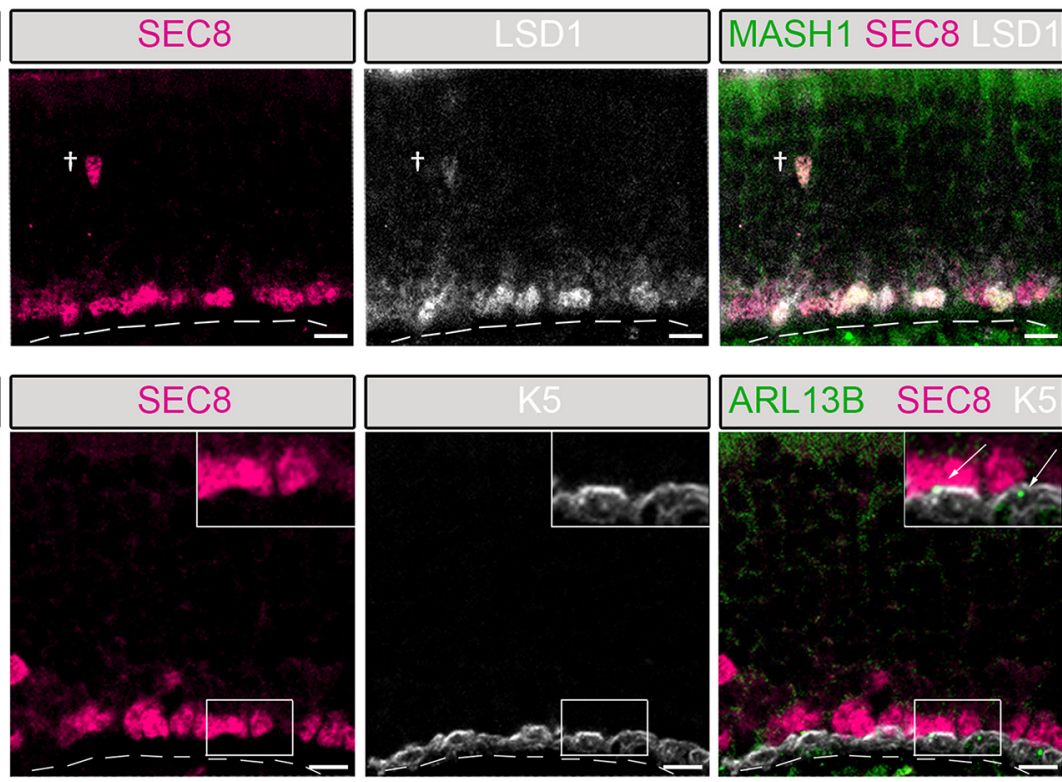

D

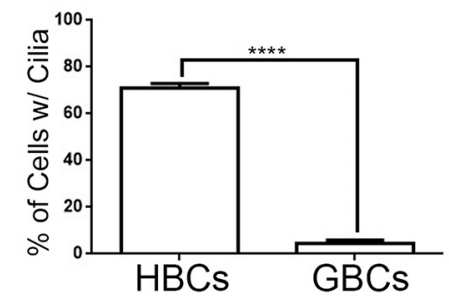

Figure 2. $H B C s$ are the predominant ciliated olfactory basal stem cell. Immunofluorescence staining was performed in the olfactory epithelium of wild-type mice. $A$, The canonical $G B C$ marker MASH1 colocalizes with a subset of SEC8 ${ }^{+} \mathrm{GBC}$, while, LSD1 colocalizes with a larger subset of SEC $8{ }^{+} \mathrm{GBC}$. $\boldsymbol{B}$, Few SEC8-labeled GBCs possess ARL13B-labeled cilia (see arrows) compared with $\mathrm{K} 5$-labeled HBCs (inset, magnified image). Scale bars, $10 \mu \mathrm{m}$. Dashed line, Basement membrane. +0 ccasional migrating GBC. $\mathrm{C}, \mathrm{Quantified} \mathrm{data}$ of SEC $8{ }^{+}$cells that are either MASH ${ }^{+}(\mathrm{N}=4)$ or $\mathrm{LSD}^{+}(N=4) . \boldsymbol{D}$, The percentage of HBCS $(N=6)$ and $\mathrm{GBCS}(N=6)$ that possess cilia. ${ }^{* * * *} p<0.0001$ by Student's $t$ test. Data are shown as the mean \pm SEM.

ARL13B-GFP also labeled cilia structures projecting from HBCs (Fig. 1C). To further characterize HBC cilia, the OE was immunostained for additional ciliary markers. Adenylate cyclase III (AC3) is a canonical marker of cilia projecting from OSNs but also labels cilia present on other cell types including primary neurons and astrocytes (Bishop et al., 2007; Guadiana et al., 2013; Higginbotham et al., 2013). AC3 colocalized with endogenous ARL13B (Fig. 1D) in wild-type mice, as well as ARL13B-GFP (Fig. $1 E)$ in transgenic mice. The $\mathrm{AC}^{+}{ }^{+}$cilia were also associated with p63-labeled HBCs similar to ARL13B (Fig. $1 F$ ). Finally, we used a second transgenic mouse, EGFP-CETN2, as an additional label for basal bodies (Higginbotham et al., 2004; Bangs et al., 2015). Immunostaining $\mathrm{OE}$ sections from this strain revealed the $\mathrm{AC}^{+}$ projections associated with EGFP-CETN2-labeled basal bodies (Fig. 1G). Together, these data show for the first time that the population of HBCs possesses primary cilia and indicate that OSNs are not the only ciliated cell type in the OE.

In the OE, apically located SUS cells possess projections, known as end feet, that juxtapose olfactory basal cells en route to contact with the basal lamina (Doyle et al., 2001). The purpose of these connections has yet to be elucidated; however, it has been proposed that this is a site for communication between basal cells and SUS cells (Jia and Hegg, 2010). In our analysis, we observed that the majority of $\mathrm{HBC}$ cilia project from the top of the HBCs toward the SUS cell end feet. To determine whether HBC cilia were associated with SUS cell end feet, analysis of $\mathrm{p} 63^{+} \mathrm{HBC}$ and SUS cells immunolabeled with K18 (Holbrook et al., 2011) was performed in Arl13b-EGFP ${ }^{t g}$ mice. As seen in the representative image (Fig. $1 H$ ), the cilia projecting from HBCs are in apposition to the end feet. To improve the resolution of a single SUS cell end foot, we analyzed the OE of mice intranasally injected with an adenovirus expressing GFP, in which a small subset of SUS cells are transduced (for methods, see McIntyre et al., 2012). Using this approach, it is clear that the $\mathrm{ARL}_{13 \mathrm{~B}}{ }^{+}$cilium projects into the interstitial space between the HBC and SUS cell (Fig. 1I). These data suggest the potential for cilia to act as an antenna for communication between basal cells and SUS cells, perhaps in a manner analogous to the immunological synapse (Bromley et al., 2001; Finetti et al., 2011).

\section{Cilia are present on distinct subpopulations of olfactory stem cells}

Given the close proximity of GBCs and HBCs at the base of the $\mathrm{OE}$, we assessed whether GBCs also possess primary cilia. We identified a novel pan-GBC marker to distinguish between $\mathrm{HBC}$ and GBC subpopulations. SEC8 is one of eight subunits in the exocyst complex that was initially discovered in the secretory pathway of yeast Saccharomyces cerevisae, and was proposed to contribute to various mechanisms, including protein synthesis and vesicle trafficking (Wang et al., 2004). Antibody staining for SEC8 in the OE specifically labeled a large population of GBCs overlapping with previous identified makers of GBC subpopulations (Fig. 2A). Immunostaining with antibodies to either MASH1 (also known as ASCL1; Manglapus et al., 2004), a basic helix-loop-helix transcription factor that is required in the early stages of olfactory neuron lineage (Cau et al., 1997), or LSD1, a 

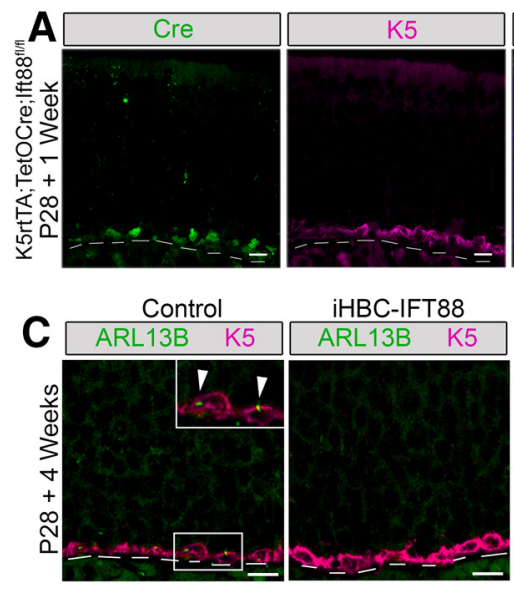
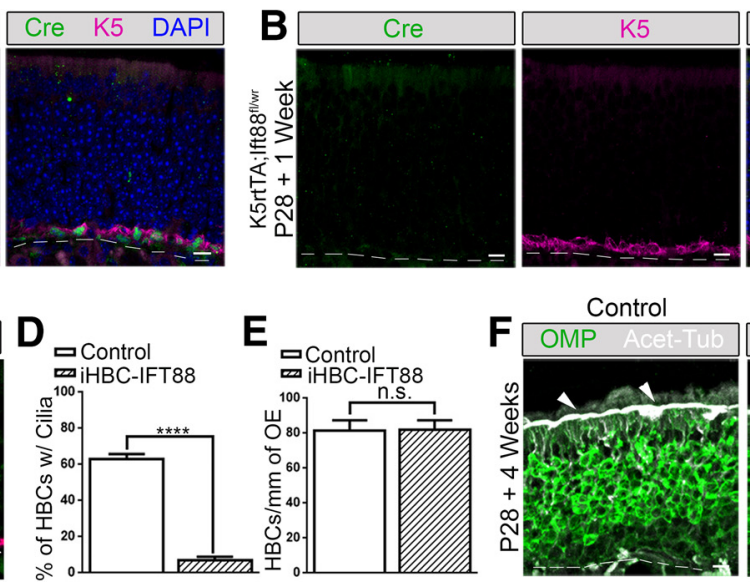

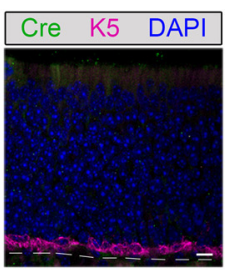

iHBC-IFT88

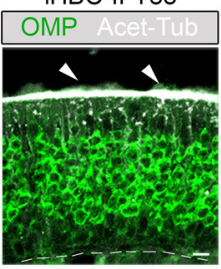

Figure 3. Cell-specific deletion of Ift88 in HBCs results in the loss of HBC cilia with no effects on OSN cilia. Control and iHBC-IFT88 mutant mice (referred to as iHBC-IFT88) were administered a dox-containing diet at P28 for 1 or 4 weeks, and immunofluorescence staining of the olfactory epithelium was performed. $A$, After 1 week of the dox-containing diet, $C$ re is present in K5-labeled HBCs of mice with K5rtTA and TetOCre alleles. B, After 1 week of the dox-containing diet, Cre is absent in mice lacking the TetOCre allele. $\boldsymbol{C}$, After 4 weeks of the dox-containing diet, in control mice but not in iHBC-IFT88 mice, K5-labeled HBCs possess Arl13b-labeled cilia. D, $\boldsymbol{E}$, Quantified data show that the percentage of HBCs that are ciliated in control mice is significantly reduced by $\sim 88.5 \%$ in iHBC-IFT88 mice, with no significant difference in the number of HBC s per millimeter of OE in control and iHBC-IFT88 mice after 4 weeks of the dox-containing diet. $F$, Acet-Tub-labeled cilia are still present in 0MP-labeled mature 0SNs (see short arrows). Scale bars, $10 \mu \mathrm{m}$. Dashed lines, Basement membrane. $N=5$ for both groups. ${ }^{* * * *} p<0.0001$. n.S., No significance by Student's $t$ test. Data are shown as the mean \pm SEM.

chromatin-modifying complex protein (Krolewski et al., 2013), in conjunction with SEC8 confirmed that SEC8 is indeed a panGBC marker. All MASH1 ${ }^{+}$or $\mathrm{LSD}^{+}{ }^{+}$cells coexpressed SEC8 (Fig. 2A). Approximately $41 \%$ of SEC $8^{+}$cells were $\mathrm{MASH} 1^{+}$, while $\sim 90 \%$ of SEC ${ }^{+}$cells were also LSD ${ }^{+}$(Fig. $2 A, C ; N=4$ ). Labeling of the OE with ARL13B and SEC8 antibodies revealed that very few $(<5 \%) \mathrm{SEC} 8{ }^{+} \mathrm{GBC}$ possess cilia, while $>70 \%$ of $\mathrm{K}^{+}{ }^{+} \mathrm{HBC}$ possess cilia (Fig. $2 B, D ; N=6$ ). These data show that $\mathrm{HBCs}$ are the predominant ciliated olfactory basal stem cells and suggest a specific role for cilia in this subpopulation of neural progenitors.

\section{Conditional deletion of intraflagellar transport machinery results in the specific loss of cilia on $\mathrm{HBCs}$}

To study the cell autonomous function of cilia in HBCs, we used a floxed allele for a gene essential for intraflagellar transport (IFT; Ift88) and an inducible Cre driver specific to HBCs in the OE (see Materials and Methods). IFT88 is a critical component of the bidirectional IFT system (Singla and Reiter, 2006; Pedersen and Rosenbaum, 2008), and conditional knockout of Ift 88 ablates cilia from specific cell types (Croyle et al., 2011; Sharma et al., 2013). Mice in which HBC cilia were ablated (K5rtTA;TetOCre;Ift8 $8^{f l / f l}$ and K5rtTA;TetOCre; Ift $88^{f l / \Delta}$ ) are hereafter referred to as iHBC-IFT88 mice, while wild-type mice (K5rtTA;TetOCre;Ift $88^{f l / w t}$ ) are hereafter referred to as control mice.

Control and iHBC-IFT88 mice were administered a doxcontaining diet to activate Cre expression (Gunther et al., 2002; Grachtchouk et al., 2011) at P28, when the OE is mature (Murdoch and Roskams, 2007). One week after dox administration, $\sim 90 \%$ of HBCs in mice with both TetOCre and K5rtTA alleles showed Cre expression (Fig. 3A). Cre expression was not detected in $\mathrm{HBCs}$ of mice that lacked the TetOCre allele (Fig. 3B). More importantly, iHBC-IFT88 mice showed a significant loss (88.5\%) of ciliated HBCs after 4 weeks of eating a dox-containing diet (Fig. 3C, D; $N=5$ ). Interestingly, loss of cilia did not result in a change in the number of HBCs (Fig. $3 E ; N=5$ ). Immunostaining with the mature OSN marker OMP and acetylated $\alpha$-tubulin (Acet-Tub) revealed no changes in OSN composition (Fig. $3 F$ ).
An increase in cilia loss on HBCs (95.6\%) was detected after 8 weeks of dox administration (Fig. $4 A, B$ ), with no effect on the number of HBCs (Fig. 4C), GBCs (Fig. 4D,E), and OSNs (Fig. $4 F, G$; control mice, $N=2$; iHBC-IFT88 mice, $N=4)$. These data demonstrate that genetic ablation of Ift 88 efficiently removes cilia from HBCs, without altering HBC quiescence or the usual maintenance of the $\mathrm{OE}$.

\section{Loss of cilia in HBCs results in the improper regeneration of} the olfactory epithelium following injury

HBCs are believed to be a quiescent population of cells unless activated by severe injury to participate in OE regeneration (Leung et al., 2007). MMI is an olfactory toxicant whose metabolites induce cell death of OSNs, SUS cells, and GBCs, but spares HBCs in the mouse OE (Brittebo, 1995; Packard et al., 2011). Four weeks after dox administration, iHBC-IFT88 and control mice were given an intraperitoneal injection of MMI $(75 \mathrm{mg} / \mathrm{kg}$ ) to chemically lesion the $\mathrm{OE}$, and were analyzed at 8 weeks after recovery (Genter et al., 1995; Bergman and Brittebo, 1999). The presence of cilia on HBCs remained significantly reduced in iHBC-IFT8 8 mice after recovery (Fig. $5 \mathrm{~A}, \mathrm{C}$; $N=5$ for both groups), while no difference in the number of HBCs was observed between iHBC-IFT88 and control mice, as indicated by the number of $\mathrm{K}^{+}$cells (Fig. $5 A, D ; N=5$ for both groups). Surprisingly, there was a significant reduction in the number of SEC ${ }^{+}$GBCs in iHBC-IFT 88 mice compared with control mice (Fig. $5 B, E ; N=5$ for both groups). In addition, the number of $\mathrm{OMP}^{+}$mature OSNs was reduced by $\sim 75 \%$ in iHBC-IFT88 mice (Fig. $5 F, G ; N=5$ for both groups). Consequently, the thickness of the $\mathrm{OE}$ was also reduced by $\sim 50 \%$ (Fig. $5 H ; N=5$ for both groups). Interestingly, no change in the number of cleaved caspase- $3^{+}$cells was observed between control and iHBC-IFT 88 mice 8 weeks after recovery, suggesting that the reduction in the number of mature OSNs and the thickness of the OE were not due to increased cell death (Fig. $5 I, J ; N=5$ for both groups). While the regeneration of neurons was not completely eliminated, the OSNs that returned appeared, in some areas of the OE, to possess acetylated $\alpha$-tubulin-labeled cilia (Fig. $5 F$ ). Since 

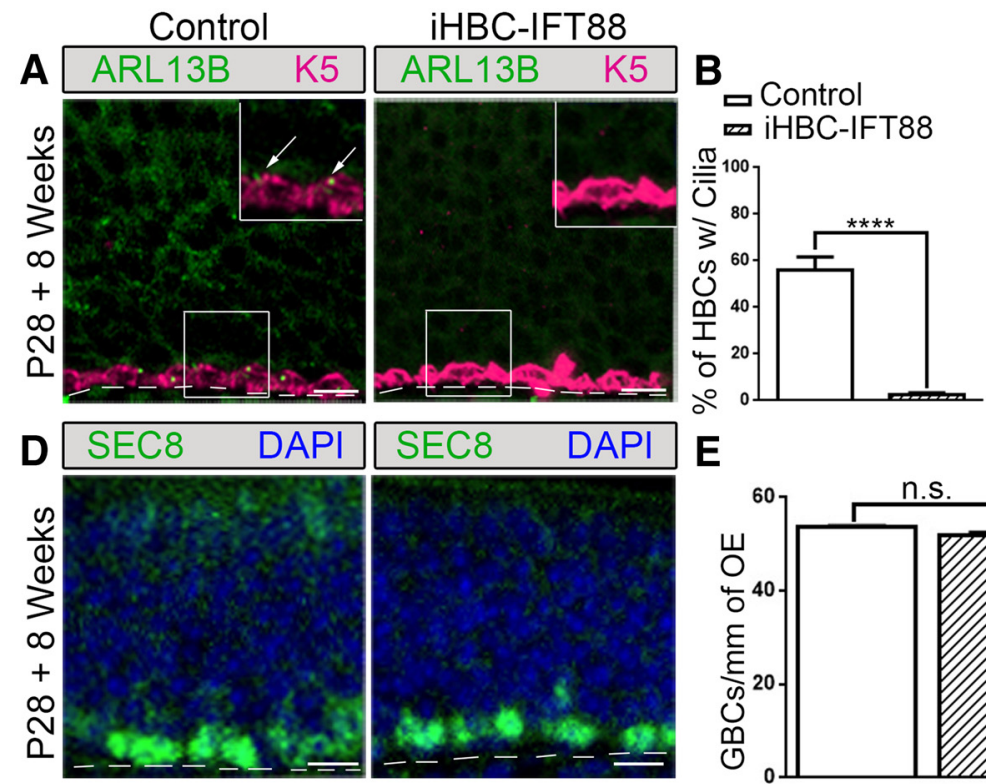

C - Control miHBC-IFT88
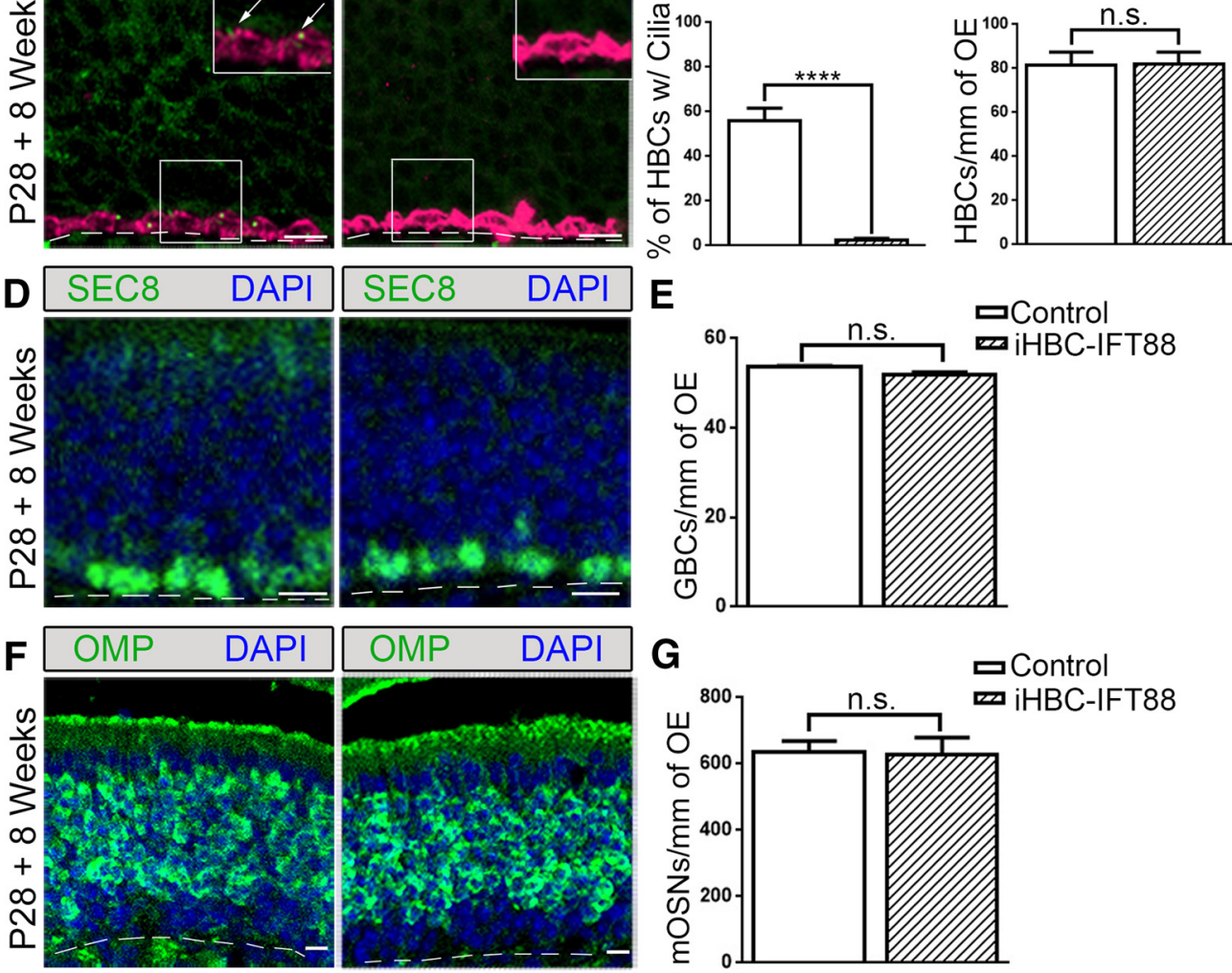

Figure 4. Loss of HBC cilia has no homeostatic effects on the cell composition of the OE. Control and iHBC-IFT88 mice were administered a doxycycline-containing diet at P28 for 8 weeks. $A$, In control mice, but not in iHBC-IFT88 mice, K5-labeled HBCs possess ARL13B-labeled cilia (see arrows; inset, magnified image). $\boldsymbol{B}, \boldsymbol{C}$, Quantified data show a significant loss of ciliated HBCs in iHBC-IFT88 mice, with no change in the number of HBCs per millimeter of OE. D, SEC8-labeled GBCs in the OE of control and iHBC-IFT88 mice. $E$, Quantified data show no significant difference in the number of GBCs per millimeter of 0 E in both groups. $F, 0 M P$-labeled mature OSNs in control and iHBC-IFT 88 mice. $\mathbf{G}$, Quantified data show no significant difference in the number of mature 0 SNs per millimeter of $0 \mathrm{E}$ between both groups. Scale bars, $10 \mu \mathrm{m}$. Dashed lines, Basement membrane. $N=2$ for control mice, $N=4$ for iHBC-IFT88 mice. ${ }^{* * * *} p<0.0001$. n.S., No significance by Student's $t$ test. Data are shown as the mean \pm SEM.

IFT88 is required for OSN cilia (McIntyre et al., 2012), the presence of ciliated OSNs in the regenerated OE suggests that these OSNs were derived from progenitors other than HBCs lacking IFT88. In our iHBC-IFT88 mice that were administered dox for 4 weeks, $\sim 12 \%$ of HBCs still possessed cilia (see Results). It is therefore likely that this remaining population of ciliated HBCs, in which IFT88 is present, contributed to regeneration of the $\mathrm{OE}$ and not HBCs lacking cilia. Another possible explanation is that OSNs in the regenerated OE were derived from residual GBCs, not from HBCs lacking IFT88. This is consistent with the MMI-induced lesion, which can leave residual GBCs (Xie et al., 2013). However, further studies involving lineage tracing are required to conclusively determine whether $\mathrm{HBCs}$ lacking cilia contribute to $\mathrm{OE}$ regeneration. Nonetheless, such significant reduction of OSNs should coincide with a decline in synaptic input into the $\mathrm{OB}$, which can be measured by the expression of $\mathrm{TH}$ in the dopaminergic interneurons of the OB (Baker et al., 1993, 1999). Following recovery, there was a significant reduction in the intensity of TH in the bulb of iHBC-IFT88 mice compared with that in control mice (Fig. $5 K, L ; p<0.0001, N=4$ for both groups), and the glomerular perimeter was significantly reduced ( $p<0.0001, N=4$ for both groups; data not shown). Together, these data indicate that, without cilia, HBCs are unable to contribute to the regeneration of the OE, potentially due to disrupted HBC proliferation, resulting in impaired OSN recovery and olfactory function.

To link the observed effects to cilia function, and not to off-target effects of IFT88 loss, we repeated these experiments using a cell-specific knockout of Arl13b (Caspary et al., 2007; Larkins et al., 2011). ARL13B is specifically localized to the cilia membrane and is required for proper ciliogenesis (Caspary et al., 2007). Moreover, mutations in Arl13b lead to loss of cilia phenotypes as well as hedgehog-related phenotypes due to the disruption in the localization and ciliary targeting of hedgehog signaling proteins (Caspary et al., 2007; Duldulao et al., 2009; Larkins et al., 2011). iHBC-ARL13B mice (K5rt TA;TetOcre;Arl13b $b^{f l f l}$ ) and control mice (K5rtTA;TetOcre; $A r l 13 b^{f l / w t}$ ) underwent the same MMI lesion paradigm as stated above. After 8 weeks of recovery, ARL13B ${ }^{+} \mathrm{HBC}$ cilia were observed in control mice but not in $\mathrm{HHBC}-\mathrm{ARL} 13 \mathrm{~B}$ mice (Fig. 6A). Similar to results observed in iHBC-IFT88 mice, the number of HBCs did not differ between control and iHBCARL13B mice (Fig. $6 B ; N=3$ for both groups). In addition, there was a significant reduction $(\sim 30 \%)$ in the number of SEC ${ }^{+}$GBCs (Fig. 6C,D; $N=3$ for both groups) as well an $\sim 75 \%$ reduction in the number of $\mathrm{OMP}^{+}$mature OSNs (Fig. $6 E, F ; N=3$ for both groups) in iHBC-ARL13B mice compared with controls. Interestingly, the apical surface of the $\mathrm{OE}$ of iHBC-ARL13B mice had a reduced number of acetylated 

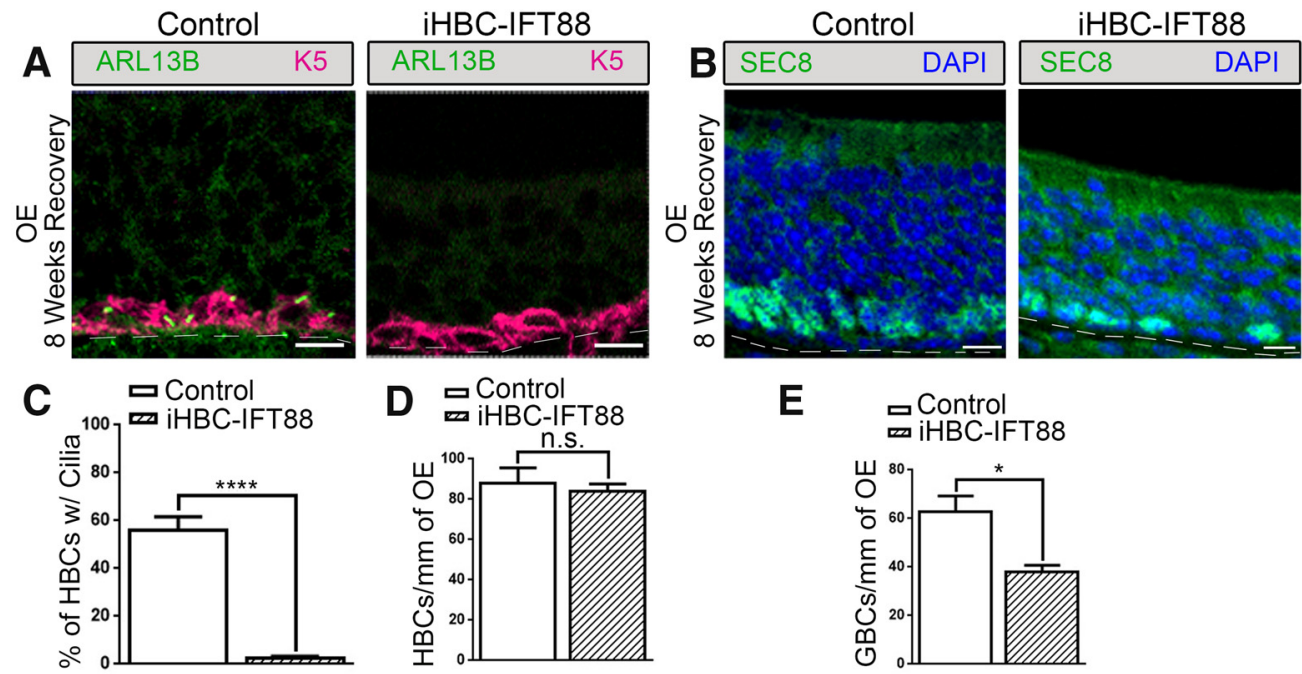

\section{E

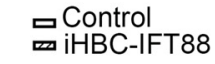

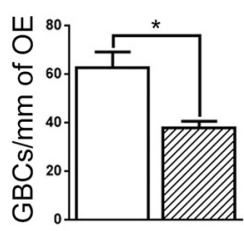

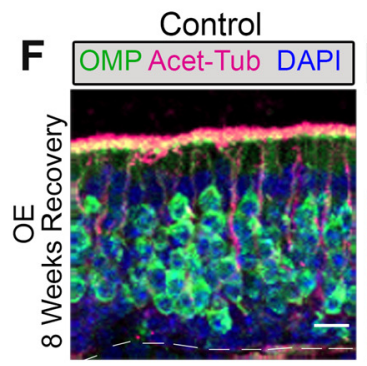

iHBC-IFT88
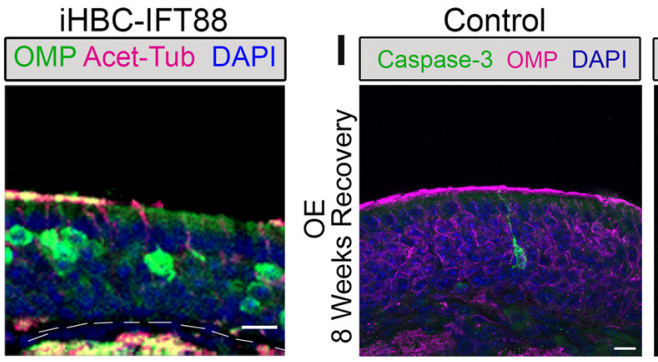

iHBC-IFT88
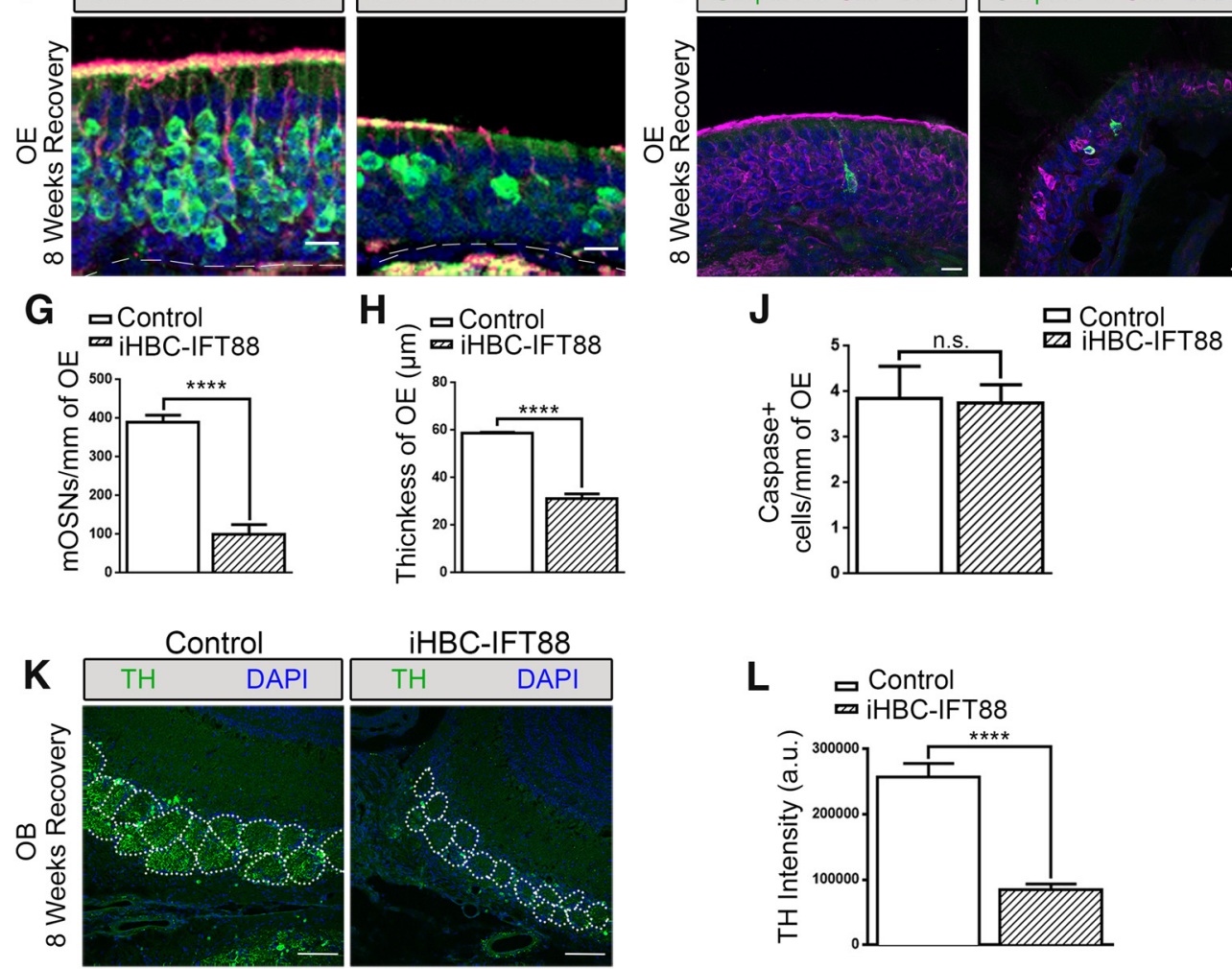

\section{iHBC-IFT88}
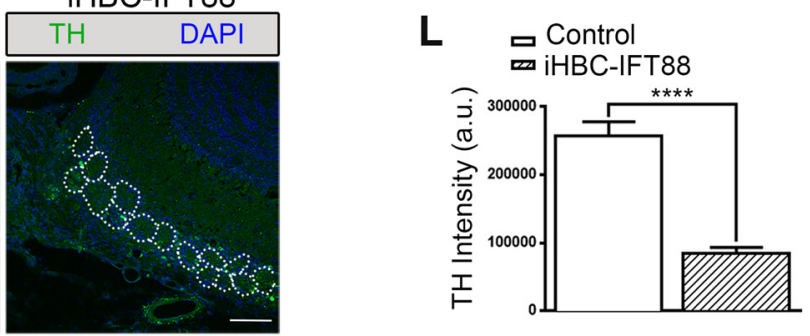

Figure 5. Loss of $\mathrm{HBC}$ cilia results in the improper regeneration of the $\mathrm{OE}$ and loss of TH expression in the $\mathrm{OB}$. Control and iHBC-IFT88 mice were administered a dox-containing diet at P28 for 4 weeks and then were given an intraperitoneal injection of $75 \mathrm{mg} / \mathrm{kg}$ methimazole to ablate the 0 E. Following 8 weeks of recovery, immunofluorescence staining was performed. $\boldsymbol{A}$, In the 0 E of control mice, but not of iHBC-IFT88 mice, K5-labeled HBCs possess ARL13B-labeled cilia. B, SEC8-labeled GBCs in the OE of control and iHBC-IFT88 mice. C, D, Quantified data show that the percentage of $\mathrm{HBC}$ s that are ciliated in control mice is significantly reduced in $\mathrm{HHBC}-\mathrm{IFT} 88$ mice with no difference in the number of $\mathrm{HBC}$ s per millimeter of $0 \mathrm{E}$ between both groups. $E$, Quantified data show a significant reduction in the number of GBCs per millimeter of $0 \mathrm{E}$. $F, 0 \mathrm{MP}$-labeled mature $0 \mathrm{SN}$ s and Acet-Tub-labeled cilia in the $0 \mathrm{E}$ of control and iHBC-IFT88 mice. G, Quantified data show a significant reduction in the number of mature 0SNs per millimeter of OE. H, A significantly thinner OE in iHBC-IFT88 mice. I, J, No difference in the number of cleaved caspase-3-labeled apoptotic cells was observed in the 0 E of control and iHBC-IFT88 mice. $\boldsymbol{K}$, TH expression within glomeruli (dotted circles) in the 0Bs of control and HHBC-IFT88 mice. L, Quantified data show that the intensity of TH measured in arbitrary units is significantly reduced in the OBs of iHBC-IFT88 mice. Scale bars, $10 \mu \mathrm{m}$. Dashed lines, Basement membrane. $N=4$ for both groups. ${ }^{*} p<0.05,{ }^{* * *} p<0.0001$. n.s., No significance by Student's $t$ test. Data are shown as the mean $\pm S E M$.

$\alpha$-tubulin-labeled OSN cilia. Together, these results not only recapitulate those observed in the iHBC-IFT 88 mice but also suggest that $A r l 13 b$ is required for $\mathrm{HBC}$ cilia function and regeneration of the $\mathrm{OE}$.
Depletion of $\mathrm{HBC}$ cilia results in the impaired development of the $\mathrm{OE}$

In mice, the OE begins to form at E10 (Murdoch and Roskams, 2007). Small numbers of p63-expressing cells first appear at 

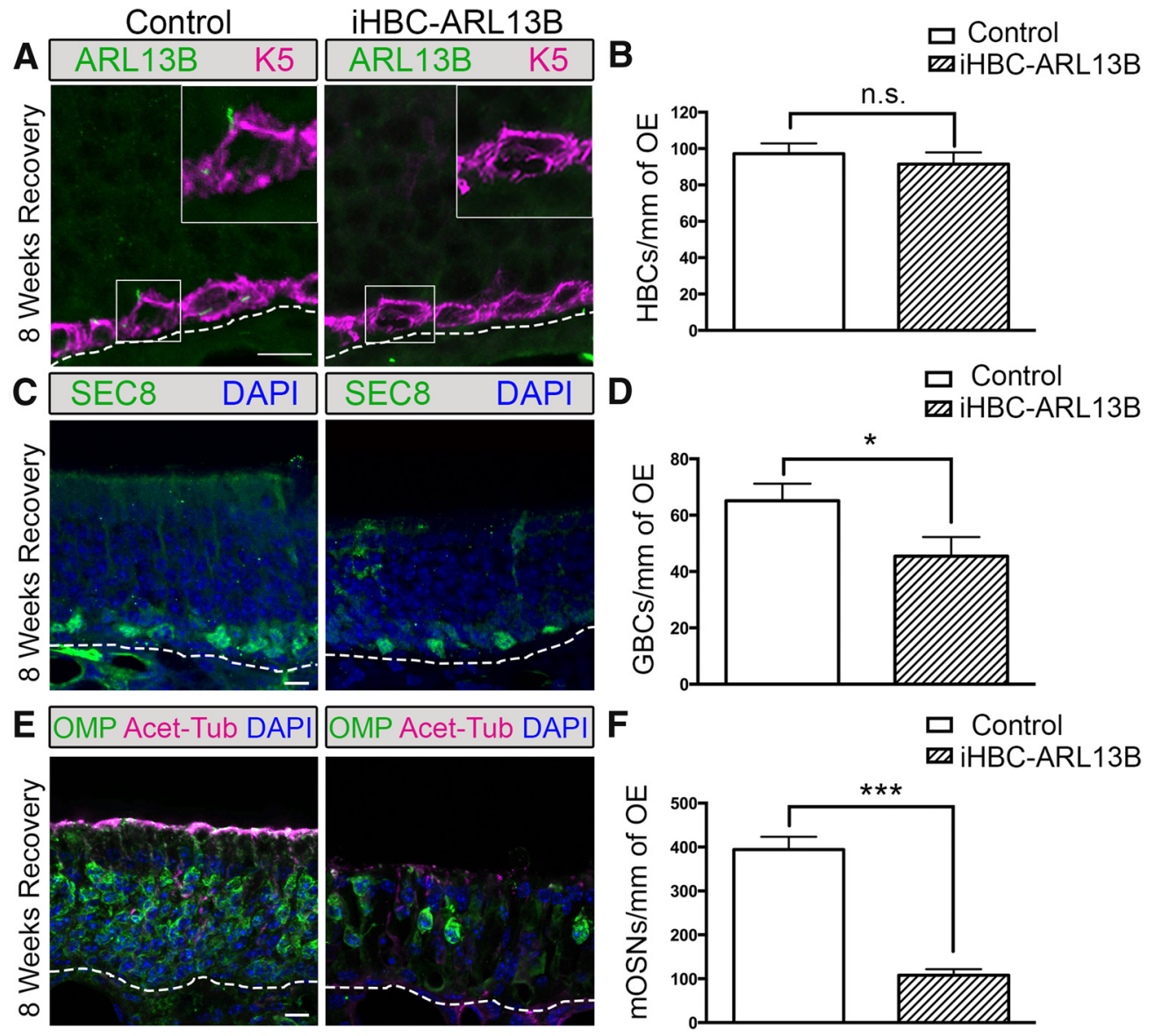

Figure 6. Loss of $A r / 13 b$ in HBCs results in the improper regeneration of the $0 E$. Control and iHBC-ARL13B mice were administered a doxycycline-containing diet at P28 for 4 weeks to induce the deletion of $A r 173 b$. Mice were then given an intraperitoneal injection of $75 \mathrm{mg} / \mathrm{kg}$ methimazole to ablate the $0 \mathrm{E}$ and were allowed 8 weeks of recovery. $A, \mathrm{~K} 5$-labeled HBCs in the OE of iHBC-ARL13B mice do not possess ARL13B-labeled cilia. $\boldsymbol{B}$, The number of HBCs per millimeter of OE in both control and HBC-ARL13B mice. C, SEC8-labeled GBCs in the OE of control and iHBC-ARL13B mice. D, Quantified data show a significant reduction in the number of GBCs per millimeter of $0 \mathrm{E}$. $\boldsymbol{E}$, OMP-labeled mature OSNs and Acet-Tub-labeled cilia in the $0 \mathrm{E}$ of control and iHBC-ARL13B mice. $\boldsymbol{F}$, Quantified data show a significant reduction in the number of mature OSNs per millimeter of $0 \mathrm{E}$. Scale bars, $10 \mu \mathrm{m}$. Dashed lines, Basement membrane. $N=3$ for both groups. ${ }^{*} p<0.05,{ }^{* * *} p<$ 0.001 . n.s., No significance by Student's $t$ test. Data are shown as the mean \pm SEM. ARL13B, ADP-ribosylation factor-like protein 13b; m0SN, mature 0SN.

E14, after the emergence of all other cell types (Packard et al., 2011). Therefore, HBCs are not believed to participate in the establishment of the OE. HBCs settle to the basal lamina, begin to express K5, and become dormant between $\sim \mathrm{E} 16$ and $\mathrm{P} 10$ (Packard et al., 2011). Exploiting this late development, iHBCIFT88 mice were administered dox starting at E16 for 4.5-5 weeks to ablate cilia during OE maturation. At P28, iHBCIFT88 mice had a near complete loss of cilia on HBCs across all regions of the OE compared with control mice (control mice, $55.47 \pm 5.02 \%$; iHBC-IFT88 mice, $5.67 \pm 2.91 \% ; p<0.01$, $N=5$ for both groups), with no difference in the total number of HBCs (control mice, $89.72 \pm 5.69 \%$; iHBC-IFT8 8 mice, $87.86 \pm 2.83 \% ; p>0.05, N=5$ for both groups). Interestingly, the dorsal-lateral region associated with ectoturbinates 2 and $2^{\prime}$ exhibited a significantly reduced number of $\mathrm{OMP}^{+}$ mature OSNs in iHBC-IFT88 mice (Fig. 7A-H). While other regions of the $\mathrm{OE}$ also exhibit a reduction in the number of mature OSNs, this reduction was variable along the anteriorposterior axis of the $\mathrm{OE}$ and was most pronounced near the midpoint of the anterior-posterior axis. Quantification of $\mathrm{OMP}^{+}$neurons in the posterior $\mathrm{OE}$ revealed a reduction in the number of mature OSNs in the dorsal-medial and dorsallateral regions, but not the ventral-medial and ventral-lateral OE (Fig. $7 E, I ; N=5$ for both groups). These data show that cilia on HBCs are important for proper neurogenesis during the development of the OE, providing evidence that HBCs participate in the establishment of this tissue that was thought to be limited to GBCs (Treloar et al., 2010).

\section{Discussion}

Within the olfactory system, it is well known that cilia from individual OSNs create a large receptive field in which an OSN can be activated by an odorant (for review, see DeMaria and Ngai, 2010). Until now it was widely believed that neurons were the sole ciliated cell type in the OE. Here, we show for the first time that primary cilia exist on a reserve population of olfactory basal stem cells, the HBCs. Furthermore, using the genetic deletion of two cilia-specific genes in HBCs, we demonstrate that primary cilia are critical for activation of the regenerative capacity of HBCs following chemical lesion. While Ift88 is well established in playing a critical role in ciliogenesis and maintenance, it has also been implicated in G1-S transition in ciliated cells (Robert et al., 2007). However in other studies, targeted deletion of Kif3a, a kinesin motor important for cilia function, shows similar phenotypic effects observed with the loss of Ift88, suggesting a common mechanism of action through the cilium (Wong et al., 2009; Berbari et al., 2013). In our study, we have validated the results observed through the deletion of Ift 88 by the targeted removal of 


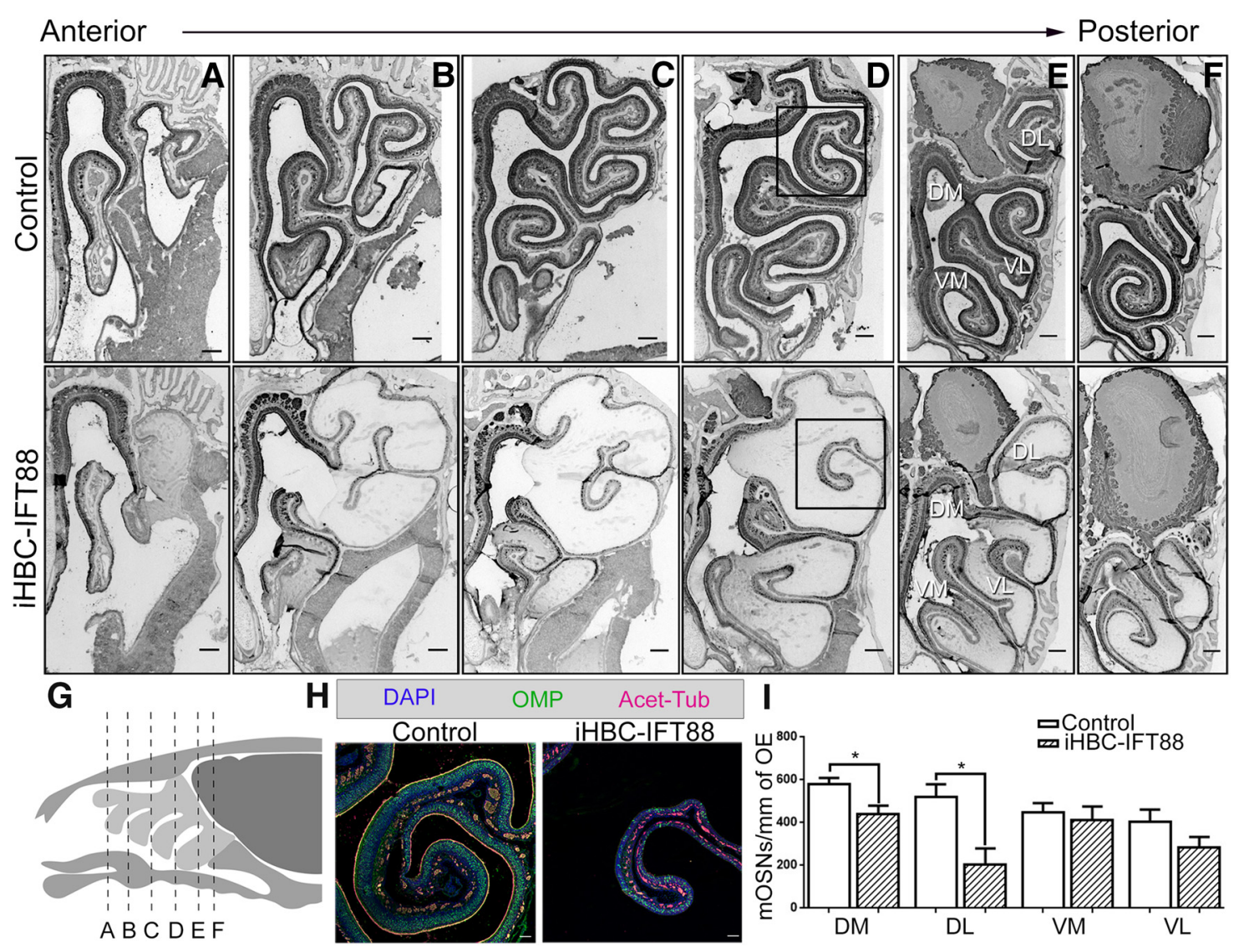

Figure 7. Loss of HBC cilia results in the impaired development of regions in the 0 E. Control and iHBC-IFT88 mice were treated with a doxycycline-containing diet at E16 for $4.5-5$ weeks and were analyzed at P28 with immunofluorescence staining of the 0 E. A-F, OMP-labeled mature OSNs in anterior-posterior sections of control and iHBC-IFT 88 mice. Scale bars, $200 \mu \mathrm{m}$. G, Illustration depicting the location of sections $\boldsymbol{A}-\boldsymbol{F}$ in a sagittal view of the mouse olfactory organ. $\boldsymbol{H}$, Magnified view of the boxed region in $\boldsymbol{D}$ with OMP-labeled mature OSNs and Acet-Tub-labeled cilia in the OE of control and iHBC-IFT88 mice. Scale bars, $50 \mu \mathrm{m}$. I, Quantified data show that the number of mature 0SNs per millimeter of OE in iHBC-IFT88 mice is significantly reduced specifically in dorsal-lateral and medial regions of the $0 \mathrm{E}$, but not in ventral regions. $N=5$ for both groups. ${ }^{*} p<0.05$ by Student's $t$ test. Data are shown as the mean $\pm S E M$. DL, Dorsal-lateral; DM, dorsal-medial; $\mathrm{VL}$, ventral-lateral; VM, ventral-medial.

Arl13b. The loss of $A r l 13 b$ has previously been demonstrated to affect neural development, and mutations in Arl13b underlie human ciliopathies (Caspary et al., 2007; Cantagrel et al., 2008; Higginbotham et al., 2012; Zhang et al., 2013). As Ift88 and Arl13b serve different roles in cilia function, the similar phenotypes observed in two different mutant lines support the conclusion that the loss in regenerative capacity of HBCs is due to dysfunctional primary cilia.

HBCs are long-lived quiescent progenitors that are activated only after extensive lesioning of the OE in which SUS cells and GBCs are depleted (Leung et al., 2007). The mechanism by which HBCs become activated remains unknown, however, SUS cell end feet have been previously shown to terminate on HBCs (Holbrook et al., 1995). Given that the present findings demonstrate an anatomical localization of the HBC cilia relative to SUS cell end feet, it is possible that HBC cilia may act to sense cues from the SUS cells regarding the health of the OE. This signaling paradigm may be analogous to the immunological synapse that forms between a $T$ cell and an antigen-presenting cell functioning to orchestrate signals that drive T-cell activation (for review, see Bromley et al., 2001). Following injury to the OE, signaling is conceivably altered between SUS cells and HBCs, resulting in activation of the quiescent HBCs. Without cilia, HBCs are unlikely to detect signals necessary for proliferation and/or differentiation. Additional support for an SUS cell-HBC connection in regenerating the $\mathrm{OE}$ comes from different lesion models. In
OSN-specific lesions, where the deaths of SUS cells and GBCs are spared, HBCs remain quiescent, and the GBCs are the leading contributor to regeneration (Leung et al., 2007; Makino et al., 2009). However, when lesions result in SUS cell and GBC death, HBCs become active and contribute to regeneration (Leung et al., 2007; Jia et al., 2010). These findings suggest that the death of SUS cells stimulates HBCs to proliferate and contribute to regeneration. However, an alternative explanation that cannot be ruled out based on current lesion models is whether signaling occurs between GBCs and HBCs, and how such signaling may contribute to $\mathrm{HBC}$ proliferation and $\mathrm{OE}$ regeneration. Interestingly, negative-feedback signaling is known to occur in the OE, as is observed between neuronal and stem/progenitor cells, to control self-replication and differentiation of the stem progenitor cell population (Beites et al., 2005; Gokoffski et al., 2010). It is therefore plausible that such feedback signaling may occur between GBCs and HBCs via HBC cilia, and that this signaling is lost when a lesion results in $\mathrm{GBC}$ death, resulting in $\mathrm{HBC}$ activation. In either case, whether the injury results in the release of a stimulatory signal or the loss of a tonic inhibitory cue between HBCs and other cell types remains to be determined.

Quiescent adult stem cells typically forgo cell cycle decisions to respond to transient environment signals sensed through the cilia (Plotnikova et al., 2009). These signals include the Notch, Wnt, and hedgehog pathways, each of which are strongly linked to neurogenesis in the brain (Kumamoto et al., 2012; Tong et al., 
2014). The Wnt pathway has been previously implicated in OE proliferation and neurogenesis during development and regeneration (Wang et al., 2011; Chen et al., 2014). In contrast, Notch signaling appears to participate in the development of supporting cells but not neurons in the OE (Manglapus et al., 2004; Krolewski et al., 2012). Currently, there is no evidence for the role of the hedgehog pathway in OE development. However, canonical hedgehog signaling is strongly linked to cilia in numerous other systems (for review, see Goetz and Anderson, 2010). Numerous hedgehog pathway components dynamically localize to cilia, while the disruption of cilia results in aberrant Hedgehog signal transduction and impaired morphogenesis in specific organ systems (for review, see Berbari et al., 2009).

While the signaling pathways may be shared, the phenotypic effects of cilia loss differ between ciliated cell types, including various stem cells. In the adult skin, loss of cilia on basal cells resulted in the proliferation of cells in the interfollicular epidermis with subsequent perturbation of epidermal homeostasis (Croyle et al., 2011). In contrast, the conditional ablation of primary cilia postnatally from NSCs in the hippocampus led to a reduction in amplifying progenitor cells without altering the number of quiescent NSCs (Amador-Arjona et al., 2011). In addition, primary cilia in the cerebellum are required for the expansion of the neural progenitor pool (Chizhikov et al., 2007). Similarly, a recent report (Tong et al., 2014) suggested that localized ablation of cilia in NSCs in the ventricular SVZ (V-SVZ) decreases neurogenesis only in the ventral V-SVZ. These data in NSCs are similar to what we observed with a loss of cilia from HBCs in the OE: no change in the number of HBCs, but a reduction in the neurogenesis of the OE. Together, these data suggest the convergence of a common cilia ablation phenotype between neural stem cells as opposed to epidermis.

During development, neural stem cells are important for early neurogenesis and morphogenesis of the OE (Gokoffski et al., 2010). While maturing GBCs that migrate from the apical surface clearly contribute to organogenesis (Cau et al., 2002), the precise role of HBCs is unclear. Evidence from a lineagetrace mouse model suggests that upon their establishment in the $\mathrm{OE}$ at $\mathrm{P} 10, \mathrm{HBCs}$ do participate in neurogenesis (Iwai et al., 2008). Our data support the notion of HBC-driven neurogenesis in early postnatal development of the OE and suggest that cilia on $\mathrm{HBCs}$ are required for normal OE development. Interestingly, the loss of OSNs observed in the developing $\mathrm{OE}$ was regional, whereas in the recovering $\mathrm{OE}$ it was global. We speculate that these differences can be attributed to the temporal and spatial release of morphogens during development that are synchronized after severe injury to the OE (Vedin et al., 2009). Nevertheless, our data demonstrate a clear role for HBCs and their cilia in the developing OE.

Our finding of cilia on HBCs and their importance in neurogenesis reveals a potential novel mechanism for the etiology of olfactory dysfunction. It is now well recognized that anosmia is a clinical manifestation of ciliopathies, a growing class of pleiotropic genetic disorders that are traditionally associated with the loss of cilia on OSNs. However, the ability to maintain a functional olfactory system throughout life depends on the presence of a stem cell population. While the OE undergoes constant neurogenesis, there is a net loss of neurons over time due to reduced stem cell function (Ducray et al., 2002; Conley et al., 2003). Changes that alter cilia function on HBCs could hasten this decline and contribute to age-related olfactory loss. Moreover, ciliopathy patients may show increased susceptibility to chemical insult to the OE. Work here suggests that impaired neurogenesis may be a new unforeseen mechanism for olfactory dysfunction in congenital anosmias.

\section{References}

Alvarez-Buylla A, Garcia-Verdugo JM (2002) Neurogenesis in adult subventricular zone. J Neurosci 22:629-634. Medline

Amador-Arjona A, Elliott J, Miller A, Ginbey A, Pazour GJ, Enikolopov G, Roberts AJ, Terskikh AV (2011) Primary cilia regulate proliferation of amplifying progenitors in adult hippocampus: implications for learning and memory. J Neurosci 31:9933-9944. CrossRef Medline

Bachmanov AA, Reed DR, Beauchamp GK, Tordoff MG (2002) Food intake, water intake, and drinking spout side preference of 28 mouse strains. Behav Genet 32:435-443. CrossRef Medline

Baker H, Morel K, Stone DM, Maruniak JA (1993) Adult naris closure profoundly reduces tyrosine hydroxylase expression in mouse olfactory bulb. Brain Res 614:109-116. CrossRef Medline

Baker H, Cummings DM, Munger SD, Margolis JW, Franzen L, Reed RR, Margolis FL (1999) Targeted deletion of a cyclic nucleotide-gated channel subunit (OCNC1): biochemical and morphological consequences in adult mice. J Neurosci 19:9313-9321. Medline

Bangs FK, Schrode N, Hadjantonakis AK, Anderson KV (2015) Lineage specificity of primary cilia in the mouse embryo. Nat Cell Biol 17:113122. CrossRef Medline

Barber PC (1982) Neurogenesis and regeneration in the primary olfactory pathway of mammals. Bibl Anat 12-25.

Beites CL, Kawauchi S, Crocker CE, Calof AL (2005) Identification and molecular regulation of neural stem cells in the olfactory epithelium. Exp Cell Res 306:309-316. CrossRef Medline

Berbari NF, O'Connor AK, Haycraft CJ, Yoder BK (2009) The primary cilium as a complex signaling center. Curr Biol 19:R526-R535. CrossRef Medline

Berbari NF, Sharma N, Malarkey EB, Pieczynski JN, Boddu R, Gaertig J, Guay-Woodford L, Yoder BK (2013) Microtubule modifications and stability are altered by cilia perturbation and in cystic kidney disease. Cytoskeleton 70:24-31. CrossRef Medline

Bergman U, Brittebo EB (1999) Methimazole toxicity in rodents: covalent binding in the olfactory mucosa and detection of glial fibrillary acidic protein in the olfactory bulb. Toxicol Appl Pharmacol 155:190-200. CrossRef Medline

Bishop GA, Berbari NF, Lewis J, Mykytyn K (2007) Type III adenylyl cyclase localizes to primary cilia throughout the adult mouse brain. J Comp Neurol 505:562-571. CrossRef Medline

Brittebo EB (1995) Metabolism-dependent toxicity of methimazole in the olfactory nasal mucosa. Pharmacol Toxicol 76:76-79. CrossRef Medline

Bromley SK, Burack WR, Johnson KG, Somersalo K, Sims TN, Sumen C, Davis MM, Shaw AS, Allen PM, Dustin ML (2001) The immunological synapse. Annu Rev Immunol 19:375-396. CrossRef Medline

Caggiano M, Kauer JS, Hunter DD (1994) Globose basal cells are neuronal progenitors in the olfactory epithelium: a lineage analysis using a replicationincompetent retrovirus. Neuron 13:339-352. CrossRef Medline

Calof AL, Chikaraishi DM (1989) Analysis of neurogenesis in a mammalian neuroepithelium: proliferation and differentiation of an olfactory neuron precursor in vitro. Neuron 3:115-127. CrossRef Medline

Cantagrel V, Silhavy JL, Bielas SL, Swistun D, Marsh SE, Bertrand JY, Audollent S, Attié-Bitach T, Holden KR, Dobyns WB, Traver D, Al-Gazali L, Ali BR, Lindner TH, Caspary T, Otto EA, Hildebrandt F, Glass IA, Logan CV, Johnson CA, et al. (2008) Mutations in the cilia gene ARL13B lead to the classical form of Joubert syndrome. Am J Hum Genet 83:170-179. CrossRef Medline

Carter LA, MacDonald JL, Roskams AJ (2004) Olfactory horizontal basal cells demonstrate a conserved multipotent progenitor phenotype. J Neurosci 24:5670-5683. CrossRef Medline

Caspary T, Larkins CE, Anderson KV (2007) The graded response to Sonic Hedgehog depends on cilia architecture. Dev Cell 12:767-778. CrossRef Medline

Cau E, Gradwohl G, Fode C, Guillemot F (1997) Mash1 activates a cascade of bHLH regulators in olfactory neuron progenitors. Development 124 : 1611-1621. Medline

Cau E, Casarosa S, Guillemot F (2002) Mash1 and Ngn1 control distinct steps of determination and differentiation in the olfactory sensory neuron lineage. Development 129:1871-1880. Medline

Chen M, Tian S, Yang X, Lane AP, Reed RR, Liu H (2014) Wnt-responsive 
Lgr5(+) globose basal cells function as multipotent olfactory epithelium progenitor cells. J Neurosci 34:8268-8276. CrossRef Medline

Chizhikov VV, Davenport J, Zhang Q, Shih EK, Cabello OA, Fuchs JL, Yoder BK, Millen KJ (2007) Cilia proteins control cerebellar morphogenesis by promoting expansion of the granule progenitor pool. J Neurosci 27: 9780-9789. CrossRef Medline

Conley DB, Robinson AM, Shinners MJ, Kern RC (2003) Age-related olfactory dysfunction: cellular and molecular characterization in the rat. Am J Rhinol 17:169-175. Medline

Costanzo RM (1991) Regeneration of olfactory receptor cells. Ciba Found Symp 160:233-242. Medline

Croyle MJ, Lehman JM, O'Connor AK, Wong SY, Malarkey EB, Iribarne D, Dowdle WE, Schoeb TR, Verney ZM, Athar M, Michaud EJ, Reiter JF, Yoder BK (2011) Role of epidermal primary cilia in the homeostasis of skin and hair follicles. Development 138:1675-1685. CrossRef Medline

Delling M, DeCaen PG, Doerner JF, Febvay S, Clapham DE (2013) Primary cilia are specialized calcium signalling organelles. Nature 504:311-314. CrossRef Medline

DeMaria S, Ngai J (2010) The cell biology of smell. J Cell Biol 191:443-452. CrossRef Medline

Diamond I, Owolabi T, Marco M, Lam C, Glick A (2000) Conditional gene expression in the epidermis of transgenic mice using the tetracyclineregulated transactivators tTA and rTA linked to the keratin 5 promoter. J Invest Dermatol 115:788-794. CrossRef Medline

Doyle KL, Khan M, Cunningham AM (2001) Expression of the intermediate filament protein nestin by sustentacular cells in mature olfactory neuroepithelium. J Comp Neurol 437:186-195. CrossRef Medline

Ducray A, Bondier JR, Michel G, Bon K, Millot JL, Propper A, Kastner A (2002) Recovery following peripheral destruction of olfactory neurons in young and adult mice. Eur J Neurosci 15:1907-1917. CrossRef Medline

Duldulao NA, Lee S, Sun Z (2009) Cilia localization is essential for in vivo functions of the Joubert syndrome protein Arl13b/Scorpion. Development 136:4033-4042. CrossRef Medline

Edge AS, Chen ZY (2008) Hair cell regeneration. Curr Opin Neurobiol 18: 377-382. CrossRef Medline

Finetti F, Paccani SR, Rosenbaum J, Baldari CT (2011) Intraflagellar transport: a new player at the immune synapse. Trends Immunol 32:139-145. CrossRef Medline

Gage FH (2000) Mammalian neural stem cells. Science 287:1433-1438. CrossRef Medline

Genter MB, Deamer NJ, Blake BL, Wesley DS, Levi PE (1995) Olfactory toxicity of methimazole: dose-response and structure-activity studies and characterization of flavin-containing monooxygenase activity in the Long-Evans rat olfactory mucosa. Toxicol Pathol 23:477-486. CrossRef Medline

Goetz SC, Anderson KV (2010) The primary cilium: a signalling centre during vertebrate development. Nat Rev Genet 11:331-344. CrossRef Medline

Gokoffski KK, Kawauchi S, Wu HH, Santos R, Hollenbeck PLW, Lander AD, Calof AL (2010) Feedback regulation of neurogenesis in the mammalian olfactory epithelium: new insights from genetics and systems biology. In: The neurobiology of olfaction (Menini A, ed), pp 241-266. Boca Raton, FL: CRC.

Grachtchouk M, Pero J, Yang SH, Ermilov AN, Michael LE, Wang A, Wilbert D, Patel RM, Ferris J, Diener J, Allen M, Lim S, Syu LJ, Verhaegen M, Dlugosz AA (2011) Basal cell carcinomas in mice arise from hair follicle stem cells and multiple epithelial progenitor populations. J Clin Invest 121:1768-1781. CrossRef Medline

Graziadei PP, Graziadei GA (1979) Neurogenesis and neuron regeneration in the olfactory system of mammals. I. Morphological aspects of differentiation and structural organization of the olfactory sensory neurons. J Neurocytol 8:1-18. CrossRef Medline

Guadiana SM, Semple-Rowland S, Daroszewski D, Madorsky I, Breunig JJ, Mykytyn K, Sarkisian MR (2013) Arborization of dendrites by developing neocortical neurons is dependent on primary cilia and type 3 adenylyl cyclase. J Neurosci 33:2626-2638. CrossRef Medline

Gunther EJ, Belka GK, Wertheim GB, Wang J, Hartman JL, Boxer RB, Chodosh LA (2002) A novel doxycycline-inducible system for the transgenic analysis of mammary gland biology. FASEB J 16:283-292. CrossRef Medline

Haycraft CJ, Zhang Q, Song B, Jackson WS, Detloff PJ, Serra R, Yoder BK (2007) Intraflagellar transport is essential for endochondral bone formation. Development 134:307-316. CrossRef Medline
Higginbotham H, Bielas S, Tanaka T, Gleeson JG (2004) Transgenic mouse line with green-fluorescent protein-labeled Centrin 2 allows visualization of the centrosome in living cells. Transgenic Res 13:155-164. CrossRef Medline

Higginbotham H, Eom TY, Mariani LE, Bachleda A, Hirt J, Gukassyan V, Cusack CL, Lai C, Caspary T, Anton ES (2012) Arl13b in primary cilia regulates the migration and placement of interneurons in the developing cerebral cortex. Dev Cell 23:925-938. CrossRef Medline

Higginbotham H, Guo J, Yokota Y, Umberger NL, Su CY, Li J, Verma N, Hirt J, Ghukasyan V, Caspary T, Anton ES (2013) Arl13b-regulated cilia activities are essential for polarized radial glial scaffold formation. Nat Neurosci 16:1000-1007. CrossRef Medline

Holbrook EH, Szumowski KE, Schwob JE (1995) An immunochemical, ultrastructural, and developmental characterization of the horizontal basal cells of rat olfactory epithelium. J Comp Neurol 363:129-146. CrossRef Medline

Holbrook EH, Wu E, Curry WT, Lin DT, Schwob JE (2011) Immunohistochemical characterization of human olfactory tissue. Laryngoscope 121: 1687-1701. CrossRef Medline

Huard JM, Youngentob SL, Goldstein BJ, Luskin MB, Schwob JE (1998) Adult olfactory epithelium contains multipotent progenitors that give rise to neurons and non-neural cells. J Comp Neurol 400:469-486. CrossRef Medline

Irigoín F, Badano JL (2011) Keeping the balance between proliferation and differentiation: the primary cilium. Curr Genomics 12:285-297. CrossRef Medline

Iwai N, Zhou Z, Roop DR, Behringer RR (2008) Horizontal basal cells are multipotent progenitors in normal and injured adult olfactory epithelium. Stem Cells 26:1298-1306. CrossRef Medline

Jang W, Chen X, Flis D, Harris M, Schwob JE (2014) Label-retaining, quiescent globose basal cells are found in the olfactory epithelium. J Comp Neurol 522:731-749. CrossRef Medline

Jia C, Hegg CC (2010) NPY mediates ATP-induced neuroproliferation in adult mouse olfactory epithelium. Neurobiol Dis 38:405-413. CrossRef Medline

Jia C, Roman C, Hegg CC (2010) Nickel sulfate induces location-dependent atrophy of mouse olfactory epithelium: protective and proliferative role of purinergic receptor activation. Toxicol Sci 115:547-556. CrossRef Medline

Kasahara K, Miyoshi K, Murakami S, Miyazaki I, Asanuma M (2014) Visualization of astrocytic primary cilia in the mouse brain by immunofluorescent analysis using the cilia marker Arl13b. Acta Med Okayama 68: 317-322. Medline

Krolewski RC, Packard A, Jang W, Wildner H, Schwob JE (2012) Ascll (Mash1) knockout perturbs differentiation of nonneuronal cells in olfactory epithelium. PLoS One 7:e51737. CrossRef Medline

Krolewski RC, Packard A, Schwob JE (2013) Global expression profiling of globose basal cells and neurogenic progression within the olfactory epithelium. J Comp Neurol 521:833-859. CrossRef Medline

Kumamoto N, Gu Y, Wang J, Janoschka S, Takemaru K, Levine J, Ge S (2012) A role for primary cilia in glutamatergic synaptic integration of adultborn neurons. Nat Neurosci 15:399-405, S1. CrossRef Medline

Larkins CE, Aviles GD, East MP, Kahn RA, Caspary T (2011) Arl13b regulates ciliogenesis and the dynamic localization of Shh signaling proteins. Mol Biol Cell 22:4694-4703. CrossRef Medline

Leung CT, Coulombe PA, Reed RR (2007) Contribution of olfactory neural stem cells to tissue maintenance and regeneration. Nat Neurosci 10:720726. CrossRef Medline

Lie DC, Song H, Colamarino SA, Ming GL, Gage FH (2004) Neurogenesis in the adult brain: new strategies for central nervous system diseases. Annu Rev Pharmacol Toxicol 44:399-421. CrossRef Medline

Makino N, Ookawara S, Katoh K, Ohta Y, Ichikawa M, Ichimura K (2009) The morphological change of supporting cells in the olfactory epithelium after bulbectomy. Chem Senses 34:171-179. CrossRef Medline

Manglapus GL, Youngentob SL, Schwob JE (2004) Expression patterns of basic helix-loop-helix transcription factors define subsets of olfactory progenitor cells. J Comp Neurol 479:216-233. CrossRef Medline

McIntyre JC, Davis EE, Joiner A, Williams CL, Tsai IC, Jenkins PM, McEwen DP, Zhang L, Escobado J, Thomas S, Szymanska K, Johnson CA, Beales PL, Green ED, Mullikin JC, Mullikin JC, Sabo A, Muzny DM, Gibbs RA, Attié-Bitach T, et al. (2012) Gene therapy rescues cilia defects and re- 
stores olfactory function in a mammalian ciliopathy model. Nat Med 18:1423-1428. CrossRef Medline

Mucenski ML, Wert SE, Nation JM, Loudy DE, Huelsken J, Birchmeier W, Morrisey EE, Whitsett JA (2003) beta-Catenin is required for specification of proximal/distal cell fate during lung morphogenesis. J Biol Chem 278:40231-40238. CrossRef Medline

Murdoch B, Roskams AJ (2007) Olfactory epithelium progenitors: insights from transgenic mice and in vitro biology. J Mol Histol 38:581-599. CrossRef Medline

Packard A, Schnittke N, Romano RA, Sinha S, Schwob JE (2011) DeltaNp63 regulates stem cell dynamics in the mammalian olfactory epithelium. J Neurosci 31:8748-8759. CrossRef Medline

Pedersen LB, Rosenbaum JL (2008) Intraflagellar transport (IFT) role in ciliary assembly, resorption and signalling. Curr Top Dev Biol 85:23-61. CrossRef Medline

Plotnikova OV, Pugacheva EN, Golemis EA (2009) Primary cilia and the cell cycle. Methods Cell Biol 94:137-160. CrossRef Medline

Robert A, Margall-Ducos G, Guidotti JE, Brégerie O, Celati C, Bréchot C, Desdouets C (2007) The intraflagellar transport component IFT88/polaris is a centrosomal protein regulating G1-S transition in non-ciliated cells. J Cell Sci 120:628-637. CrossRef Medline

Sharma N, Malarkey EB, Berbari NF, O'Connor AK, Vanden Heuvel GB, Mrug M, Yoder BK (2013) Proximal tubule proliferation is insufficient to induce rapid cyst formation after cilia disruption. J Am Soc Nephrol 24:456-464. CrossRef Medline

Singla V, Reiter JF (2006) The primary cilium as the cell's antenna: signaling at a sensory organelle. Science 313:629-633. CrossRef Medline

Su CY, Bay SN, Mariani LE, Hillman MJ, Caspary T (2012) Temporal deletion of Arl13b reveals that a mispatterned neural tube corrects cell fate over time. Development 139:4062-4071. CrossRef Medline
Tong CK, Han YG, Shah JK, Obernier K, Guinto CD, Alvarez-Buylla A (2014) Primary cilia are required in a unique subpopulation of neural progenitors. Proc Natl Acad Sci U S A 111:12438-12443. CrossRef Medline

Treloar HB, Miller AM, Ray A, Greer CA (2010) Development of the olfactory system. In: The neurobiology of olfaction (Menini A, ed), pp 131156. Boca Raton, FL: CRC.

Vedin V, Molander M, Bohm S, Berghard A (2009) Regional differences in olfactory epithelial homeostasis in the adult mouse. J Comp Neurol 513: 375-384. CrossRef Medline

Wang S, Liu Y, Adamson CL, Valdez G, Guo W, Hsu SC (2004) The mammalian exocyst, a complex required for exocytosis, inhibits tubulin polymerization. J Biol Chem 279:35958-35966. CrossRef Medline

Wang YZ, Yamagami T, Gan Q, Wang Y, Zhao T, Hamad S, Lott P, Schnittke N, Schwob JE, Zhou CJ (2011) Canonical Wnt signaling promotes the proliferation and neurogenesis of peripheral olfactory stem cells during postnatal development and adult regeneration. J Cell Sci 124:1553-1563. CrossRef Medline

Wong SY, Seol AD, So PL, Ermilov AN, Bichakjian CK, Epstein EH Jr, Dlugosz AA, Reiter JF (2009) Primary cilia can both mediate and suppress Hedgehog pathway-dependent tumorigenesis. Nat Med 15:1055-1061. CrossRef Medline

Xie F, Fang C, Schnittke N, Schwob JE, Ding X (2013) Mechanisms of permanent loss of olfactory receptor neurons induced by the herbicide 2,6dichlorobenzonitrile: effects on stem cells and noninvolvement of acute induction of the inflammatory cytokine IL-6. Toxicol Appl Pharmacol 272:598-607. CrossRef Medline

Zhang Q, Hu J, Ling K (2013) Molecular views of Arf-like small GTPases in cilia and ciliopathies. Exp Cell Res 319:2316-2322. CrossRef Medline 